\title{
Bexarotene-Induced Dyslipidemia and Central Hypothyroidism in a Patient With Sezary Syndrome
}

\author{
Baris Sariakcali ${ }^{\mathrm{a}}$, Esma Jamaspishvilib ${ }^{\mathrm{b}}$, Mehtap Evran ${ }^{\mathrm{a}, \mathrm{c}}$, Murat Sert ${ }^{\mathrm{a}}$, Tamer Tetiker ${ }^{\mathrm{a}}$
}

\begin{abstract}
We report a patient with Sezary syndrome (cutaneous T-cell lymphoma) who developed severe central hypothyroidism and mixed hyperlipidemia due to the bexarotene treatment (a synthetic retinoid analog with specific affinity for retinoid $\mathrm{X}$ receptor used in the treatment of Sezary syndrome). The other pituitary functions were found to be normal. These are rare adverse effects of bexarotene treatment and there are a few case reports in literature. Management of the adverse events could be done by nicotinic acid or fenofibrates, statins and L-thyroxin replacement. In this case we managed the patient by nicotinic acid, statin and L-thyroxin for 2 years.
\end{abstract}

Keywords: Sezary syndrome; Bexarotene; Dyslipidemia; Central hypothyroidism

\section{Introduction}

Bexarotene is a retinoid $\mathrm{X}$ receptor-selective retinoid (a rexinoid), which is approved in the US for the treatment of cutaneous manifestations of cutaneous T-cell lymphoma (CTCL) in patients refractory to at least one prior systemic therapy and in Europe for the treatment of patients with skin manifestations of advanced-stage CTCL refractory to at least one systemic therapy $[1,2]$. It is recommended as a second-line therapy for the treatment of mycosis fungoides and Sezary syndrome in a number of national and international guide-

\footnotetext{
Manuscript accepted for publication May 20, 2014

${ }^{a}$ Division of Endocrinology, Department of Internal Medicine, Cukurova University Medical Faculty, Adana 01330, Turkey

${ }^{\mathrm{b}}$ Division of Endocrinology, Department of Internal Medicine, Tbilisi

State Medical University, Adana 01330, Turkey

${ }^{\mathrm{c} C}$ Corresponding Author: Mehtap Evran, Division of Endocrinology,

Department of Internal Medicine, Cukurova University Medical

Faculty, Adana 01330, Turkey. Email: mehtap.evran@hotmail.com
}

doi: http://dx.doi.org/10.14740/jem222w lines $[2,3]$. Bexarotene treatment is associated with unavoidable side effects, in particular hypertriglyceridemia with hypercholesterolemia and central hypothyroidism, which are manageable with adequate concomitant medications and are reversible on cessation of treatment $[1,2]$.

Here we report our patient with Sezary syndrome who was treated with bexarotene, which had side effects of severe central hypothyroidism and mixed hyperlipidemia.

\section{Case Report}

A 46-year-old male was diagnosed with mycosis fungoides by skin biopsy in March 3, 2011. He received several treatment including narrow-band UVB (NB-UVB), psoralen plus UVA (PUVA), interferon alfa 2b (three times weekly) between 2011 and 2012 with variable success. On March 6, 2012, oral bexarotene ( $75 \mathrm{mg}$ twice daily) was initiated for the treatment of new skin lesions, and the dose was increased to $300 \mathrm{mg}$ twice daily for flare-up of the skin lesions. Periodic laboratory follow-up including lipid profile and thyroid functions were performed. In May 2012, he presented to endocrinology clinic with fatigue. On physical examination, he looked pale and sluggish with a blood pressure of 120/70 $\mathrm{mm} \mathrm{Hg}$. On laboratory examination, anterior pituitary hormones were completely normal except thyroid-stimulating hormone (TSH) level. Serum TSH and FT3, FT4 levels were consistent with the central hypothyroidism (Table 1). Magnetic resonance imaging (MRI) of the pituitary gland revealed normal size, signal and dynamic contrast enhancement. Liver and kidney functions tests were normal. Following the increased serum triglyceride and LDL levels and decreased TSH levels, he was started on niascor $500 \mathrm{mg}$, atorvastatin $80 \mathrm{~g}$ and L-thyroxine $100 \mu \mathrm{g}$ per day with appropriate diet. After 3 months follow-up, the serum lipids level and thyroid hormones level were in normal ranges (Table 1). His symptoms improved. The patient continued followup visits with 3 months intervals. One of these monitoring visits (in December 2012), the analysis of thyroid function was found to be decreased. We had to increase the dosage of L-thyroxine (T4) to $300 \mu \mathrm{g}$ once daily. Anti-microsomal and anti-thyroglobulin antibodies were found to be not increased. 
Table 1. Basal and Follow-Up Biochemical Parameters of the Case

\begin{tabular}{|c|c|c|c|c|}
\hline $\begin{array}{l}\text { Analysis (normal } \\
\text { range) }\end{array}$ & $\begin{array}{l}\text { Basal (before) the } \\
\text { treatment }\end{array}$ & At 3 months & At 6 months & At 2 years \\
\hline $\begin{array}{l}\text { T. cholesterol }(<200 \\
\mathrm{mg} / \mathrm{dL})\end{array}$ & 463 & 228 & 256 & 218 \\
\hline $\begin{array}{l}\text { HDL cholesterol }(\mathrm{f}>50 \\
\mathrm{m}>40 \mathrm{mg} / \mathrm{dL})\end{array}$ & 22.9 & 39.3 & 29.5 & 39.5 \\
\hline $\begin{array}{l}\text { Triglycerides }(<200 \mathrm{mg} / \\
\mathrm{dL})\end{array}$ & 864 & 280 & 341 & 167 \\
\hline VLDL-Chol. (mg/dL) & 172.8 & 56 & 60 & - \\
\hline $\begin{array}{l}\text { LDL-Chol. }(<160 \mathrm{mg} / \\
\text { dL) }\end{array}$ & 267 & 133 & 158 & 125 \\
\hline TSH (0.34 - $5.6 \mathrm{mIU} / \mathrm{L})$ & 0.12 & $<0.01$ & 0.04 & 0.01 \\
\hline $\begin{array}{l}\text { Free T4 }(0.61-1.12 \mathrm{ng} / \\
\mathrm{dL})\end{array}$ & 0.49 & 0.77 & 0.51 & 0.72 \\
\hline $\begin{array}{l}\text { Free T3 }(2.3-4.2 \mathrm{pg} / \\
\mathrm{mL})\end{array}$ & 2.1 & 2.84 & 2.43 & 2.29 \\
\hline
\end{tabular}

We could maintain bexarotene therapy in this patient with euthyroid state and normal lipid levels.

\section{Discussion}

Bexarotene rapidly and reversibly suppresses serum TSH. The mechanism by which bexarotene can cause central hypothyroidism is not completely understood but is postulated to be secondary to direct suppression of TSH subunit synthesis, TSH secretion, and TSH clearance [4]. Experimental studies about bexarotene have revealed that the rexinoid LG268 suppresses TSH promoter activity, TSH mRNA synthesis and TSH secretion, whereas no effect on TRH synthesis was observed $[1,4]$. In addition to these observations, rexinoids may influence peripheral thyroid hormone metabolism through increased or decreased type 1 deiodinase activity or by the induction of hepatic detoxification enzymes $[1,5]$. Serum TSH and FT3, FT4 of our case had been in normal ranges before bexarotene therapy. During the bexarotene therapy serum TSH, FT3, FT4 levels progressively decreased in 2 months and clinical hypothyroid findings were developed (Table 1).

Clinical and hormonal data were consistent with the central hypothyroidism. We also scanned the pituitary gland for any infiltrating lesions or tumors, and it was found normal. We started T4 replacement therapy and in about 3 months of the therapy, clinical findings improved and serum T3 and T4 levels increased to normal levels.

Dyslipidemia has been also reported as a result of bexarotene therapy. A study in apolipoprotein (APO) E2 knock-in mice showed that bexarotene increased the expression of hepatic genes involved in triglyceride (TG) synthesis and very low-density lipoprotein (VLDL) production. In addition, activating angiopoietin-like protein 3 in vivo and apoCIII in vitro, factors that are both inhibitors of the TG-hydrolyzing activity of lipoprotein lipase, could affect TG clearance [6]. Also bexarotene increases LDL and decreases HDL levels by activating endogenous cholesteryl ester transfer protein (CETP) production [7]. Serum triglyceride and LDL levels of our case were consistent with these findings. In addition we may speculate that hypothyroidism could also be an effect on serum lipid metabolism. We had to treat the patients with niascore and atorvastatin as well as T4 replacement.

In conclusion, bexarotene treatment may induce central hypothyroidism and hyperlipidemia. Hence, those patients who are treated with this agent must be followed for these serious adverse effects. If it develops, T4 replacement and anti-lipidemic treatment can successfully correct the clinical data of table. 


\section{Conflict of Interest}

The authors declare that there is no conflict of interest that could be perceived as prejudicing the impartiality of the research reported.

\section{Funding}

This research did not receive any specific grant from any funding agency in the public, commercial or not-for-profit sector.

\section{Author Contributions}

All authors contributed to the writing of this paper. Baris Sariakcali was the treating physician of the patient.

\section{References}

1. Smit JW, Stokkel MP, Pereira AM, Romijn JA, Visser TJ. Bexarotene-induced hypothyroidism: bexarotene stimulates the peripheral metabolism of thyroid hormones. J Clin Endocrinol Metab. 2007;92(7):2496-2499.

2. Assaf C, Bagot M, Dummer R, Duvic M, Gniadecki R, Knobler R, Ranki A, et al. Minimizing adverse side-ef- fects of oral bexarotene in cutaneous T-cell lymphoma: an expert opinion. Br J Dermatol. 2006;155(2):261-266.

3. Trautinger F, Knobler R, Willemze R, Peris K, Stadler $\mathrm{R}$, Laroche L, D'Incan M, et al. EORTC consensus recommendations for the treatment of mycosis fungoides/ Sezary syndrome. Eur J Cancer. 2006;42(8):1014-1030.

4. Golden WM, Weber KB, Hernandez TL, Sherman SI, Woodmansee WW, Haugen BR. Single-dose rexinoid rapidly and specifically suppresses serum thyrotropin in normal subjects. J Clin Endocrinol Metab. 2007;92(1):124-130.

5. Sharma V, Hays WR, Wood WM, Pugazhenthi U, St Germain DL, Bianco AC, Krezel W, et al. Effects of rexinoids on thyrotrope function and the hypothalamic-pituitary-thyroid axis. Endocrinology. 2006;147(3):14381451.

6. Vu-Dac N, Gervois P, Torra IP, Fruchart JC, Kosykh V, Kooistra T, Princen HM, et al. Retinoids increase human apo C-III expression at the transcriptional level via the retinoid $\mathrm{X}$ receptor. Contribution to the hypertriglyceridemic action of retinoids. J Clin Invest. 1998;102(3):625-632.

7. de Vries-van der Weij J, de Haan W, Hu L, Kuif M, Oei HL, van der Hoorn JW, Havekes LM, et al. Bexarotene induces dyslipidemia by increased very low-density lipoprotein production and cholesteryl ester transfer protein-mediated reduction of high-density lipoprotein. Endocrinology. 2009;150(5):2368-2375. 